\title{
Brain copper storage after genetic long-term correction in a mouse model of Wilson disease
}

Ricarda Uerlings, BSc, Daniel Moreno, PhD, Oihana Murillo, PhD, Cristina Gazquez, PhD, Rubén HernándezAlcoceba, MD, PhD, Gloria González-Aseguinolaza, PhD, and Ralf Weiskirchen, PhD

Neurol Genet 2018;4:e243. doi:10.1212/NXG.0000000000000243

\author{
Correspondence \\ Dr. González-Aseguinolaza \\ ggasegui@unav.es or \\ Dr. Weiskirchen \\ rweiskirchen@ukaachen.de
}

Wilson disease is a rare autosomal recessive condition caused by mutations in the coppertransporting ATPase ATP7B gene (OMIM: 606882) provoking loss of function and resulting in variable hepatic and neurologic symptoms. Currently, the treatment of Wilson disease focuses on achieving a negative copper balance either with chelators (e.g., D-penicillamine, trientine, and tetrathiomolybdate) or zinc, which reduces copper absorption, or a combination thereof. ${ }^{1}$ However, these lifelong treatment regimens often cause side effects and do not restore normal copper metabolism.

Recently, the construction and characterization of an AAV8 vector system in which the human $A T P 7 B$ cDNA is placed under the control of the liver-specific human al-antitrypsin (AAT) promoter has been described. ${ }^{2}$ This targeted therapy showed clear and robust long-term benefit in the $A t p 7 b^{-/-}$mouse model, representing a well-established model for therapeutic interventions such as drug, gene, and cell therapy. ${ }^{3}$ In particular, the AAV8 vector induced a dosedependent therapeutic effect as assessed by reduction in serum transaminases and urinary copper excretion, normalization of serum holo-ceruloplasmin, and restoration of physiologic biliary copper excretion in response to copper overload without any side effects. ${ }^{2}$ Although the findings of this study are overall promising, the therapeutic effects from reducing cerebral copper have not been tested yet.

We have previously analyzed in detail the age-dependent accumulation of copper in the $A t p 7 b^{-/-}$ mouse model in which a portion of the Atp $7 b$ exon 2 is replaced by a disruption cassette incorporating an early termination codon and a frameshift mutation giving rise to a shortened mRNA, which is not capable to produce detectable levels of ATP7B protein. ${ }^{4}$ This former analysis in respective mice revealed about a twofold stable increase in copper throughout the brain parenchyma, whereas in periventricular regions, copper was decreased by a factor of up to 3.5 , especially in the fourth ventricle where lumen was systematically discernable in null but not in wild-type animals. ${ }^{5}$ It is known that these impairments of homeostatic mechanisms in brain copper metabolism are connected with distinct cognitive alterations, neurodegeneration, and morphologic changes of normal astrocyte architecture, which are the consequences of varying regional susceptibility to copper within the brain. ${ }^{5}$ Therefore, for the successful development of future adeno-associated virus (AAV)-based gene therapy as a novel option in the management of human Wilson disease, it will be of fundamental importance to investigate the effect of the transgene on cerebral copper concentration and distribution.

To test whether the AAV8-based therapy allows for the correction of cerebral copper overload in the $A t p 7 b$ null mice, we extended the previous study and performed laser ablation inductively coupled plasma mass spectrometry (LA-ICP-MS) on brain tissue sections of male homozygous

From the Institute of Molecular Pathobiochemistry, Experimental Gene Therapy and Clinical Chemistry (R.U., R.W.), RWTH University Hospital Aachen, Aachen, Germany; Gene Therapy and Regulation of Gene Expression Program (D.M., O.M., C.G., R.H.-A., G.G.-A.), CIMA, Foundation for Applied Medical Research, University of Navarra; Instituto de Investigacion Sanitaria de Navarra (IDISNA) (D.M., O.M., C.G., R.H-.A., G.G.-A.); and Vivet-Therapeutics (G.G.-A.), Pamplona, Spain.

The Article Processing Charge was funded by the authors.

Comment on animal manipulation: Animal experimentation was approved by the Ethical Committee for Animal Testing of the University of Navarra.

Funding information and disclosures are provided at the end of the article. Full disclosure form information provided by the authors is available with the full text of this article at Neurology.org/NG.

This is an open access article distributed under the terms of the Creative Commons Attribution-NonCommercial-NoDerivatives License 4.0 (CC BY-NC-ND), which permits downloading and sharing the work provided it is properly cited. The work cannot be changed in any way or used commercially without permission from the journal. 
Atp $7 b$ null mice. To do so, 6-week-old Atp $7 b^{-/-}$mice $(\mathrm{n}=6)$ received an injection of AAV8 expressing a codon optimized (co) version of an $A T P 7 B$ mini gene (miATP7B) engineered to allow optimize expression in mouse. The construct was directed under transcriptional control of the human AAT promoter (AAV-AAT-co-miATP7B) at a dose of $1 \times 10^{11} \mathrm{vg} /$ mouse, whereas another group of $A t p 7 b^{-1-}$ mice $(n=5)$ of the same age was left untreated. Moreover, we have incorporated a group of age-matched $A t p 7 b^{+/-}$littermates $(\mathrm{n}=6)$ taken as a healthy control group because these heterozygous animals show no alterations of copper metabolism and expression of the ATP7B protein compared with wild-type controls. ${ }^{3}$

Animals were sacrificed 14 weeks later, brains were harvested, and $30-\mu \mathrm{m}$ thick tissue cryosections were prepared for LAICP-MS metal imaging. This technique has multielement capability and allows for the analysis of a large variety of biological materials with high spatial resolution. ${ }^{6}$ To visualize the concentrations of individual elements in the analyzed sections, we transmitted the measurements obtained in our LA-ICP-MS line by line scans into an Excel spreadsheet and generated parametric images using open source ELAI software recently developed by us. ${ }^{7}$ At the end, the results are processed into 2-dimensional images, which can be transformed into common file formats such as TIFF or JPG while retaining exact proportion of their $\mathrm{X} / \mathrm{Y}$ dimensions.

In our analysis, we found that the brains of animals receiving the transgene had overall lower concentrations of total cerebral copper (figure 1), most prominently noticeable in the cerebellum, cerebellar white matter, corpus callosum, 3rd and 4 th ventricles, and surrounding tissue, and a slight decrease in

Figure 1 Metal bioimaging in 30- $\mu$ m thick cryosections taken from the brains of untreated and AAV8-AAT-co-miATP7B-treated Atp7b null mouse

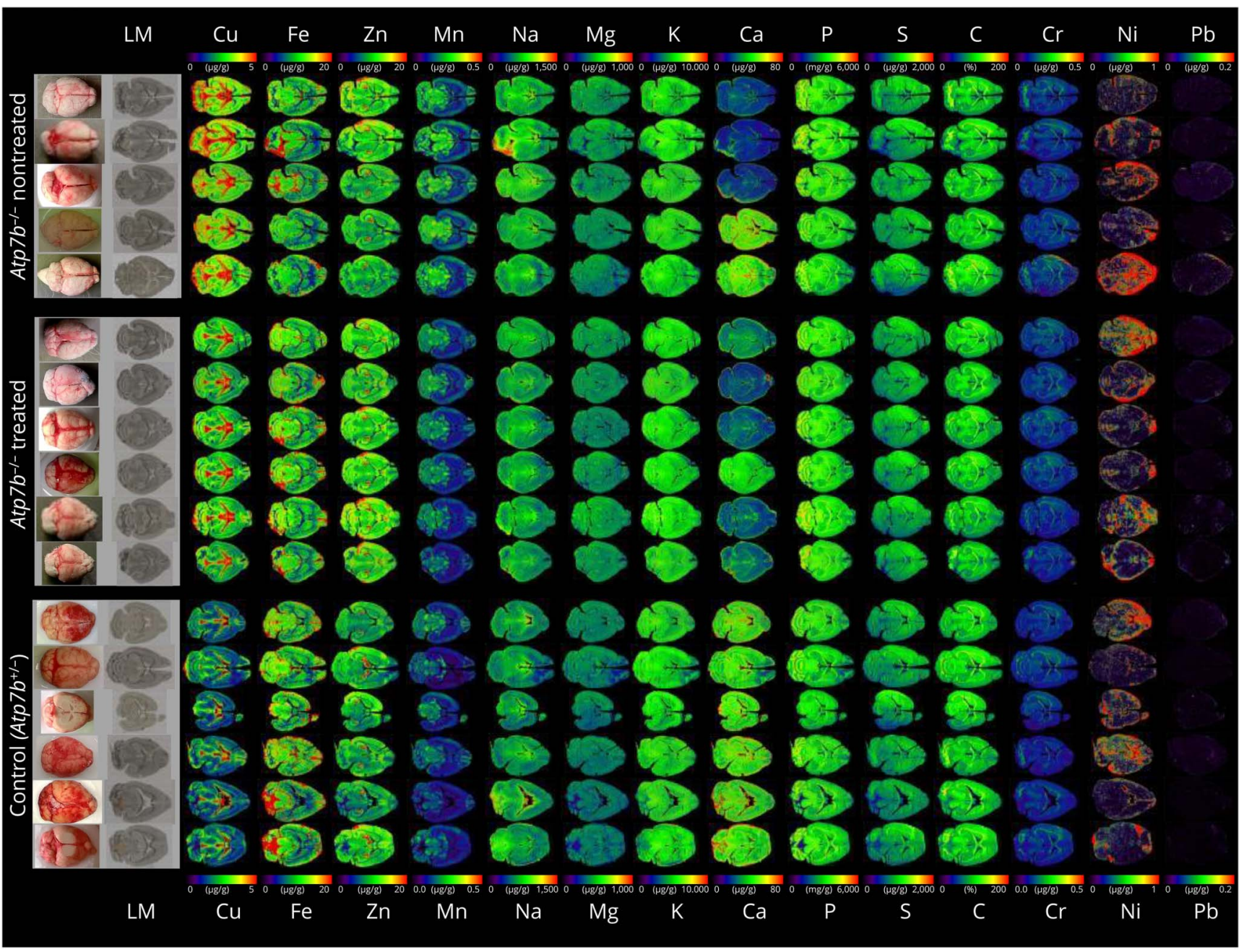

The contents of copper (Cu), iron (Fe), zinc (Zn), manganese (Mn), sodium (Na), magnesium (Mg), potassium (K), calcium (Ca), phosphorus (P), sulfur (S), carbon $(\mathrm{C})$, chromium $(\mathrm{Cr})$, nickel $(\mathrm{Ni})$, and lead $(\mathrm{Pb})$ in each section are shown. Individual images of elements were done with the ELAl software tool. ${ }^{7}$ Light microscopic (LM) images of cryosections and pictures of brains analyzed are shown for orientation in the left margin. In this analysis, Atp $7 b^{+/-}$mice served as a further control. Please note that the content of $C$ serving as reference is given in \%, whereas concentrations of all other elements are given in $\mu g / g$ liver tissue. Details about animal manipulation are given elsewhere. ${ }^{2}$ 
the basal ganglia. While the mean cerebral copper content was $3.80 \pm 0.2 \mu \mathrm{g} / \mathrm{g}$ brain tissue in the untreated group, the delivery of the transgene reduced the copper content to a mean concentration of $3.05 \pm 0.17 \mu \mathrm{g} / \mathrm{g}$. The content in the Atp $7 b^{+/-}$ control mice that show no alterations in copper metabolisms was determined to be $2.34 \pm 0.09 \mu \mathrm{g} / \mathrm{g}$. The coefficient of variation in these measurements was calculated to be $5.1 \%$ in the nontreated group, $5.7 \%$ in the treated group, and $4.0 \%$ in the control group. The concentrations of other metals including iron, zinc, manganese, sodium, magnesium, potassium, calcium, phosphorus, chromium, nickel, and lead were unaffected. These findings reveal that the delivery of AAV8AAT-co-miATP7B is capable of reducing the overall cerebral copper content without affecting other metals. Moreover, the single IV administration with AAV8-AAT-co-miATP7B provoked reduced urinary copper excretion, increased ceruloplasmin activity in blood, and reduced liver damage as indicated by lower activities in alanine transaminase (figure 2, A-C). This therapeutic effect on liver metal content was also recently demonstrated by metal bioimaging showing the overall reduction of hepatic copper throughout the tissue. ${ }^{8}$ Therefore, it is most likely that the reduction of cerebral copper in our liver-directed therapy is secondary and induced by hepatic ATP7B expression lowering systemic copper concentration. All these changes demonstrate that AAVtreated animals recovered from copper overload.

Under therapy, we noticed no alterations in neurologic functions. However, this is not surprising because the most striking phenotype of this experimental Wilson disease model is the formation of gross anatomical liver abnormalities, and no neurologic alterations have been reported. Only the progeny of homozygous mutant females demonstrate neurologic symptoms at young age. ${ }^{3}$ However, when these neurologic symptoms are apparent, respective animals do not survive beyond 2 weeks of age. ${ }^{9}$ Thereafter, alterations in behavior provoked by cerebral copper overload are negligible. As such, the lack of severe neurologic alterations is a limitation of the current model when comparing with human Wilson disease.

We hope that our note will further encourage clinical studies aiming to use AAV therapeutic gene transfer in patients with Wilson disease. The ability to elicit robust and long-term $A T P 7 B$ gene expression in vivo with AAV vectors might become an attractive therapy to complement the mainstay therapy for Wilson disease of relying on chelating agents and medications that block excess copper absorption.

\section{Author contributions}

R. Uerlings: performance and evaluation of LA-ICP-MS measurements. D. Moreno, C. Gazquez, and O. Murillo: animal experimentation. R. Hernández-Alcoceba, G. GonzálezAseguinolaza, and R. Weiskirchen: design of the study and writing of the manuscript.

\section{Acknowledgment}

The authors thank Astrid Küppers (Zentralinstitut für Engineering, Elektronik und Analytik, Forschungszentrum Jülich, Jülich, Germany) for excellent technical assistance in LA-ICPMS measurements. They acknowledge Drs Nick Weber and Bérnard Benichou for critical comments and careful review and Dr. Andreas Matusch (Division of Molecular Neuroimaging,

Figure 2 Analysis of copper in urine and ceruloplasmin and ALT in control, untreated, and AAV8-AAT-co-miATP7B-treated Atp7b null mouse
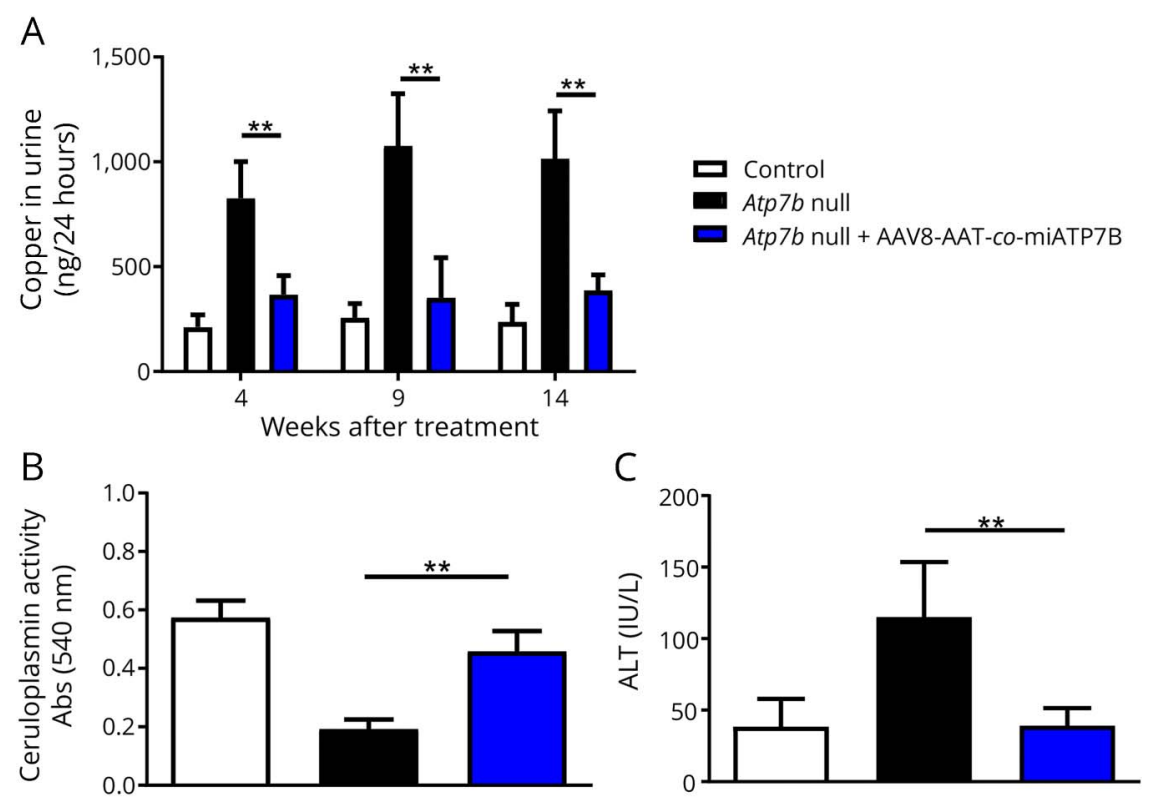
(A) Copper in 24 hour urine was analyzed 4,9 , and
14 weeks after the administration of the vector.
(B) Ceruloplasmin levels in serum were de-
termined 4 weeks after vector administration. (C)
Alanine transaminase (ALT) levels indicating liver
damage were determined 14 weeks after the
administration of the vector. $p$ values for signifi-
cance are ${ }^{* *} p<0.01$. 
Institute of Neuroscience and Medicine-2, Forschungszentrum Jülich, Germany) for help in preparing murine brains.

\section{Study funding}

$\mathrm{R}$. Weiskirchen is supported by grants from the Deutsche Forschungsgemeinschaft (SFB/TRR 57 projects P13 and Q3) and from the IZKF Aachen (Project O3-1).

\section{Disclosure}

R. Uerlings, D. Moreno, O. Murillo, and C. Gazquez report no disclosures. R. Hernández-Alcoceba has served on the editorial board of Human Gene Therapy; has participated in a project financed by Vivet Therapeutics; and has received research support from the Foundation for Applied Medical Research (FIMA). G. González-Aseguinolaza is affiliated with Vivet Therapeutics, a company focused on optimizing gene therapy approaches; holds a patent regarding AAV vector expressing ATP7B for the treatment of Wilson's disease; and has received research support from the Spanish Ministry of Economy and Competitiveness and Fundació Per Amor a l'Art. Ralf Weiskirchen has served on the editorial boards of Faculty 1000 in Medicine, Journal of Cellular Biochemistry, Hepatitis Monthly, Frontiers in Gastrointestinal Sciences (Frontiers in Physiology), The Scientific World Journal (Section Hepatology), Laboratory Animals, Frontiers in Physiology, Hepatobiliary Surgery and Nutrition, Frontiers in Pharmacology, Gastrointestinal Sciences Frontiers in Physiology, American Journal of Biochemistry and Molecular Biology, World J Biological Chemistry, EC Orthopaedics, Scientific Journal of Biology, Journal of Development Biology and Regenerative Medicine, SF Journal of Biotechnology and Biomedical Engineering, American Journal of
Clinical Microbiology and Antimicrobials, EC Gastroenterology and Digestive System, Journal of Pharmacology and Pharmaceutical Research, Stem Cells and Regenerative Medicine, American Journal of Family Medicine, American Journal of Liver \& Clinical Research, Journal of Clinical Pharmacology and Research, Annals of Proteomics and Bioinformatics, and International Journal of Experimental Biology and applied for a patent regarding pharmaceutical composition targeting the hepatic content of amyloid beta $(\mathrm{A} \beta)$ to treat liver fibrosis/cirrhosis. Full disclosure form information provided by the authors is available with the full text of this article at Neurology.org/NG.

Received December 7, 2017. Accepted in final form April 11, 2018.

\section{References}

1. Patil M, Sheth KA, Krishnamurthy AC, Devarbhavi H. A review and current perspective on Wilson disease. J Clin Exp Hepatol 2013;3:321-336.

2. Murillo O, Luqui DM, Gazquez C, et al. Long-term metabolic correction of Wilson's disease in a murine model by gene therapy. J Hepatol 2016;64:419-426.

3. Buiakova OI, Xu J, Lutsenko S, et al. Null mutation of the murine ATP7B (Wilson disease) gene results in intracellular copper accumulation and late-onset hepatic nodular transformation. Hum Mol Genet 1999;8:1665-1671.

4. Boaru SG, Merle U, Uerlings R, et al. Simultaneous monitoring of cerebral metal accumulation in an experimental model of Wilson's disease by laser ablation inductively coupled plasma mass spectrometry. BMC Neurosci 2014;15:98.

5. Scheiber IF, Mercer JF, Dringen R. Metabolism and functions of copper in brain. Prog Neurobiol 2014;116:33-57.

6. Weiskirchen R, Uerlings R. Laser ablation inductively coupled plasma mass spectrometry in biomedicine and clinical diagnosis. Cell Mol Med 2015;19:806-814.

7. Uerlings R, Matusch A, Weiskirchen R. Reconstruction of laser ablation inductively coupled plasma mass spectrometry (LA-ICP-MS) spatial distribution images in Microsoft Excel 2007. Int J Mass Spectrom 2016;395:27-35.

8. Moreno D, Murillo O, Gazquez C, et al. Visualization of the therapeutic efficacy of a gene correction approach in Wilson's disease by laser-ablation inductively coupled mass spectrometry. J Hepatol 2018;68:199-201.

9. Lutsenko S. Atp $7 b^{-1-}$ mice as a model for studies of Wilson's disease. Biochem Soc Trans 2008;36:1233-1238. 


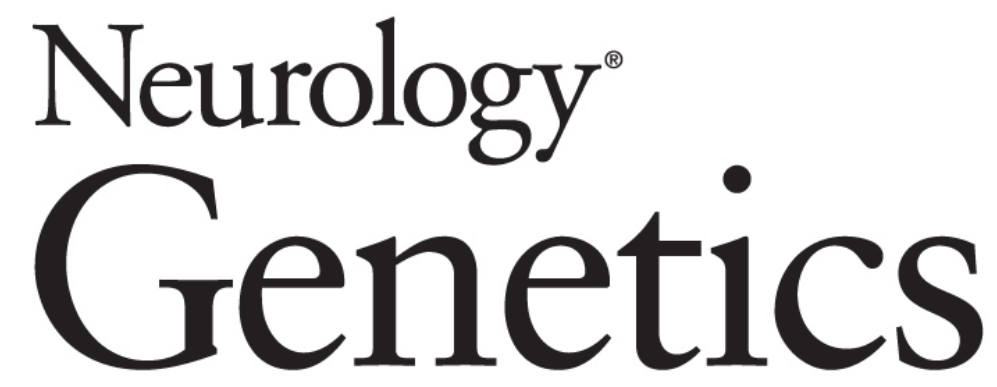

Brain copper storage after genetic long-term correction in a mouse model of Wilson disease

Ricarda Uerlings, Daniel Moreno, Oihana Murillo, et al. Neurol Genet 2018;4;

DOI 10.1212/NXG.0000000000000243

This information is current as of May 18, 2018

Neurol Genet is an official journal of the American Academy of Neurology. Published since April 2015, it is an open-access, online-only, continuous publication journal. Copyright Copyright $\odot 2018$ The Author(s). Published by Wolters Kluwer Health, Inc. on behalf of the American Academy of Neurology.. All rights reserved. Online ISSN: 2376-7839.

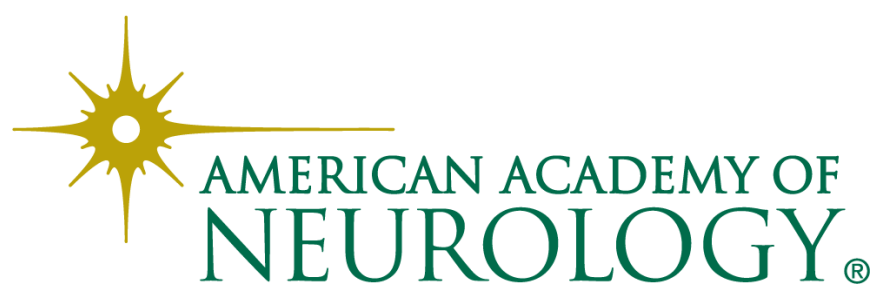




\section{Updated Information \& Services}

References

Citations

Subspecialty Collections

Permissions \& Licensing

Reprints including high resolution figures, can be found at: http://ng.neurology.org/content/4/3/e243.full.html

This article cites 9 articles, 1 of which you can access for free at: http://ng.neurology.org/content/4/3/e243.full.html\#\#ref-list-1

This article has been cited by 2 HighWire-hosted articles: http://ng.neurology.org/content/4/3/e243.full.html\#\#otherarticles

This article, along with others on similar topics, appears in the following collection(s):

\section{All Genetics}

http://ng.neurology.org//cgi/collection/all_genetics All Imaging

http://ng.neurology.org//cgi/collection/all_imaging

Gastrointestinal

http://ng.neurology.org//cgi/collection/gastrointestinal

Gene therapy

http://ng.neurology.org//cgi/collection/gene_therapy

Other toxicology

http://ng.neurology.org//cgi/collection/other_toxicology

Information about reproducing this article in parts (figures,tables) or in its entirety can be found online at:

http://ng.neurology.org/misc/about.xhtml\#permissions

Information about ordering reprints can be found online:

http://ng.neurology.org/misc/addir.xhtml\#reprintsus

Neurol Genet is an official journal of the American Academy of Neurology. Published since April 2015, it is an open-access, online-only, continuous publication journal. Copyright Copyright ( 2018 The Author(s). Published by Wolters Kluwer Health, Inc. on behalf of the American Academy of Neurology.. All rights reserved. Online ISSN: 2376-7839.

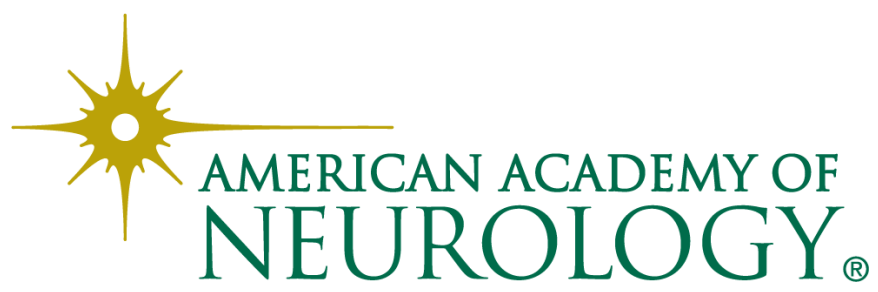

